\title{
Endoparasites in fecal samples from anatids in captivity in São Paulo, Brazil
}

\author{
Endoparasitos em amostras fecais de anatídeos em cativeiro em São Paulo, \\ Brasil
}

Fernanda Bruno (1D); Thais Aguiar Emídio² (1D; Claudiana Auxiliadora Rosa (1); Fabio Novelli Martorelli (D); Cidéli de Paula Coelho ${ }^{1}$ (B)

\begin{abstract}
1 Departamento de Pós-graduação, Faculdade de Medicina Veterinária, Universidade Santo Amaro - UNISA, São Paulo, SP, Brasil ${ }^{2}$ Departamento de graduação, Faculdade de Medicina Veterinária, Universidade Santo Amaro - UNISA, São Paulo, SP, Brasil ${ }^{3}$ Faculdade de Medicina Veterinária, Faculdades Metropolitanas Unidas - FMU, São Paulo, SP, Brasil
\end{abstract}

How to cite: Bruno F, Emídio TA, Rosa CA, Martorelli FN, Coelho CP. Endoparasites in fecal samples from anatids in captivity in São Paulo, Brazil. Braz J Vet Parasito/ 2021; 30(1): e022320. https://doi.org/10.1590/S1984-29612021009

\begin{abstract}
The objective of the present study was to identify the intestinal parasites with the highest prevalence in anatids that were reared extensively in the city of São Paulo, through coproparasitological examinations. Fecal samples $(n=108)$ were collected at two times, with an interval of two months between them, during the year 2018. The samples were constituted from a pool of feces, and one sample was collected from each enclosure. The samples were identified as belonging to 13 species of anatids (Aix galericulata, Aix sponsa, Anser abyssinia, Chenonetta jubata, Chloephaga melanoptera, Chloephaga picta, Lophodytes cucullatus, Tadorna cana, Tadorna ferrugínea, Tadorna radjah, Tadorna tadorna, Tadorna tadornoide and Tadorna variegata). Samples of birds with or without clinical symptoms of endoparasitosis were then collected. The Coproplus $®$ test was used to make the coproparasitological diagnosis and subsequently the material was examined individually, at Santo Amaro University in São Paulo. It was observed that $48.14 \%$ of the enclosures had birds infected by one or more endoparasites. Parasites of the order Coccidia presented the highest prevalence (22.22\%), followed by those of the orders Trichuroidea (10.18\%) and Ascaridia (4.63\%). Moreover, Balantidium sp. was found, the cycle and relevance of these ciliates in birds is uncertain.
\end{abstract}

Keywords: Endoparasitosis, Balantidium sp., Oocysts, Coproparasitological, birds.

\begin{abstract}
Resumo
O objetivo do presente estudo foi identificar os parasitos intestinais de maior prevalência em anatídeos provenientes de uma criação extensiva no município de São Paulo, por meio da realização de exame coproparasitológico. Foram coletadas 108 amostras fecais em dois momentos, com intervalo de dois meses entre eles, durante o ano de 2018. As amostras foram constituídas de um pool de fezes, e coletada uma amostra para cada recinto por coleta. Foi realizada a identificação das espécies e estas pertenciam a 13 espécies de anatídeos (Aix galericulata, Aix sponsa, Anser abyssinia, Chenonetta jubata, Chloephaga melanoptera, Chloephaga picta, Lophodytes cucullatus, Tadorna cana, Tadorna ferrugínea, Tadorna radjah, Tadorna tadorna, Tadorna tadornoide e Tadorna variegata). Em seguida foram coletadas as amostras de aves com sintomatologia clínica ou não de endoparasitoses. Para o diagnóstico coproparasitológico e coleta foi utilizado o teste Coproplus ${ }^{\circledR}$ e posteriormente, o material foi examinado individualmente na Universidade Santo Amaro. Observou-se que 48,14\% dos recintos possuíam animais infectados por um ou mais endoparasitos. Houve maior prevalência para parasitos da ordem Coccidia $(22,22 \%)$, seguido pela ordem Trichuroidea (10,18\%) e Ascaridia (4,63\%) e como achado o Balantidium sp. que possui ciclo e relevância incerta em aves.
\end{abstract}

Palavras-chave: Endoparasitoses, Balantidium sp., Oocistos, Coproparasitológico, aves. 


\section{Introduction}

Parasitoses exhibit a direct relationship between the host and the parasite, given that the parasitized species naturally provides the environment necessary for survival of the parasite (Santana, 2019). In domestic animals, occurrences of parasites are generally associated with management (hygiene, nutrition, type of rearing and stress), the environment and even genetic factors (Rennó et al., 2008; Santana, 2019).

Endoparasitoses of birds can be caused by helminths, especially nematode and cestodes, and by protozoa. The nematodes that occur most frequently and that are most responsible for economic losses belong to the order Ascaridida, in the families Heterakidae and Ascarididae, which include the genera Heterakis and Ascaridia, which parasitize the small intestine and are most prevalent in birds reared in closed environments with access to the soil. Both Heterakis spp. and Ascaridia spp. have eggs of ellipsoid appearance, with thick walls and a smooth surface (Corrêa, 2007). Nematodes of the genus Capillaria are detected in the small intestine of several bird species, with greatest occurrence in situations of high-density reared populations, which generally more easily become contaminated by infective forms of the parasite (Machado, 2014).

Cestodes are considered to be less pathogenic than nematodes and may infect birds, thereby causing clinical disease. Cestodes do not possess a digestive tract and feed by means of absorption of the host's intestinal content. More than a thousand species of cestodes have been identified in domestic and wild birds (Corrêa, 2007).

Among the protozoa that affect birds, those of the genus Eimeria have a major economic impact, especially among birds in captivity, through reducing their metabolic and immunological efficacy and causing mortality (Lillehoj \& Lillehoj, 2000). The oocysts of Eimeria, which are the infective form found in feces, are very resistant in the environment. These protozoa develop in a single host, with both sexual and asexual multiplication in the epithelial cells of the host's small and large intestine. This leads to alterations to the morphology and function of the intestinal villi, which varies according to the parasite load, location and species (Zacarias, 2017).

Anatids belong to the order Anseriformes, family Anatidae. They are birds that spend the majority of their lives in different aquatic environments, with preferences that vary between the species. These birds present particular morphological features and important adaptations to their biology that are connected with aquatic life, such as waterproofed feathers, short legs and webbed toes (Justo, 2019; Carvalho, 2020).

The aim of the present study was to identify the intestinal parasites of greatest prevalence among anatids, that were extensively reared in a property in the municipality of São Paulo, SP, Brazil, by means of performing coproparasitological examinations.

\section{Material and Method}

The procedures that were conducted in this study were appraised and approved by the Ethics Committee for Animal Use (CEUA) of Santo Amaro University (No. 01/2018).

Samples of anatid feces were collected at two times: April and July 2018. These birds were reared extensively on a property located in the municipality of São Paulo, SP. A total of 438 birds belonging to 13 species of anatids were sampled, as follows: Abyssinia Goose (Anser abyssinia, $\mathrm{n}=4$ ), Andean Goose (Chloephaga melanoptera, $\mathrm{n}=2$ ), Magellan Goose (Chloephaga picta, n=2), Mandarin Duck (Aix galericulata, $\mathrm{n}=164$ ), Wood Duck (Aix sponsa, $\mathrm{n}=220$ ), Maned Goose (Chenonetta jubata, $\mathrm{n}=2$ ), South African Shelduck (Tadorna cana, $\mathrm{n}=8$ ), Ruddy Shelduck (Tadorna ferrugínea, $\mathrm{n}=8$ ), Radjah Shelduck (Tadorna radjah, $\mathrm{n}=6$ ), Common Shelduck (Tadorna tadorna, $\mathrm{n}=6$ ), Australian Shelduck (Tadorna tadornoides, $\mathrm{n}=6$ ), Paradise Shelduck (Tadorna variegata, $\mathrm{n}=8$ ) and Hooded Merganser (Lophodytes cucullatus, $\mathrm{n}=2$ ).

After identification of the species, using taxonomic keys, fecal samples were collected from all 54 enclosures. At each sampling time, a pooled sample of approximately $1 \mathrm{~g}$ was collected from each enclosure, thus totaling 108 samples.

The fecal material was placed directly in the flask of the diagnostic kit that was acquired for processing the tests (Coproplus ${ }^{\circ}$, NL Diagnóstica, São Paulo, Brazil). This kit contains $13 \mathrm{ml}$ of the conserving medium SAF (sodium acetate, $2 \%$ acetic acid, $4 \%$ formalin and deionized water). Immediately after collection, the material in the flask was stirred using circular movements. It was then packed in a receptacle for transportation. All the samples were kept at room temperature until the time of analysis, as recommended by the manufacturer.

In conformity with the product instructions, the samples were again stirred using circular movements before analysis under a microscope. The sealing cap of each flask was then removed and the flasks were gently pressed so that air would escape. They were then inverted and placed on a sedimentation tray for 15 minutes. After this period, one drop of the material and another of Lugol's staining solution were placed on a glass slide, a coverslip was placed over these and the slide was examined under an optical microscope. 


\section{Results}

Out of the 54 enclosures examined, 24 gave rise to positive samples (48.14\%), with one or more endoparasites. Among the 108 samples examined, 40 (37.03\%) were positive, (37.03\%), as presented in Table 1.

Among the parasites encountered, those of the order Coccidia had the highest prevalence (22.22\%; 24/108), followed by those of the orders Trichuroidea (10.18\%; 11/108) and Ascaridia (4.63\%; 5/108).

Table 2 illustrates the parasites found in each species of anatid examined. Parasites that did not use birds in their belong to the parasitological cycle of the birds, such as Balantidium sp., were also observed (8/108).

\section{Discussion}

With the aim of obtaining results of greater representativeness regarding the endoparasites presented in the birds examined (given the impossibility of individual sampling), feces pools were collected per species (enclosure) at two different times. This procedure had previously been used in other studies on birds in captivity (Carneiro et al., 2011).

Infection with parasites of the order Coccidia occurs frequently, both in birds in captivity and in free-living birds (Pérez et al., 2008, 2009; López et, al. 2007). In other Brazilian studies on birds in captivity carried out in São Luis do Maranhão, MA (Figueiredo et al., 2018) and Botucatu, SP (Marietto-Gonçalves et al., 2009), coccids were also shown to be the most prevalent gastrointestinal parasites.

Coinfections were also found in $11 \%(12 / 108)$ of the samples tested, which accounted for $36 \%(12 / 33)$ of the positive samples. These comprised associations of coccids with Trichuroidea and/or Ascaridia. Coinfection between coccids and nematodes in anatids was also demonstrated by Lima et al. (2017), in exotic birds in Sergipe.

The parasites found in the present study are easily disseminated because they have free-living forms that are resistant to the environment, which thus favors infection of other birds in the same enclosure. Infection may cause a variety of problems for these birds, including poor-quality eggs, metabolic disorders and even death (Sesti, 2005).

Eimeriosis is caused by protozoa of the genus Eimeria. This disease, also known as avian coccidiosis, is one of the parasitic diseases of greatest economic importance in industrial poultry rearing, even though anticoccidial drugs are widely used (Luchese et al., 2007).

Balantidium sp. is an intestinal protozoon that affects mammals that become infected through ingestion of contaminated feces. After evolution of the parasite, these mammals eliminate it in their feces (Gomes et al., 2009). Although the habitual reservoirs for Balantidium sp. are humans and pigs, it has also been reported in rodents, amphibians, reptiles, fish and birds (Batista et al., 2011; Serrano-Martínez et al., 2017).

Table 1. Prevalence of parasite orders found in 108 feces pools from anatids.

\begin{tabular}{|c|c|c|c|}
\hline \multirow{3}{*}{ Parasite orders } & \multicolumn{3}{|c|}{ Positive samples (\%) } \\
\hline & $1^{\text {st }}$ collection & $2^{\text {nd }}$ collection & Total \\
\hline & $n=54(\%)$ & $n=54(\%)$ & $n=108(\%)$ \\
\hline Coccidia & $5(9.25)$ & $11(20.37)$ & $16(14.81)$ \\
\hline Trichuroidea & $1(1.85)$ & $3(5.55)$ & $4(3.70)$ \\
\hline Ascaridia & $1(1.85)$ & $\mathrm{N}$ & $1(0.92)$ \\
\hline Coccidia + Balantidium sp. & $\mathrm{N}$ & $4(7.40)$ & $4(3.70)$ \\
\hline Trichuroidea + Ascaridia + Balantidium sp. & $\mathrm{N}$ & $1(1.85)$ & $1(0.92)$ \\
\hline Coccidia + Balantidium sp. + Ascaridia & $\mathrm{N}$ & $1(1.85)$ & $1(0.92)$ \\
\hline Coccidia + Trichuroidea & $1(1.85)$ & $1(1.85)$ & $2(1.85)$ \\
\hline Coccidia + Balantidium sp. + Trichuroidea & $\mathrm{N}$ & $1(1.85)$ & $1(0.92)$ \\
\hline Trichuroidea + Ascaridia & $1(1.85)$ & $1(1.85)$ & $2(1.85)$ \\
\hline Trichuroidea + Balantidium sp. & $\mathrm{N}$ & $1(1.85)$ & $1(0.92)$ \\
\hline Total number of positive samples & $9(16.66)$ & $24(44.44)$ & $33(30.55)$ \\
\hline
\end{tabular}

$\mathrm{N}$ - negative samples 
Table 2. List of parasites encountered, per bird species.

\begin{tabular}{ccc}
\hline Bird species & & Parasite order \\
\cline { 2 - 3 } Anser abyssinia & $\mathbf{1}^{\text {st }}$ collection & $\mathbf{2}^{\text {nd }}$ collection \\
Chloephaga melanoptera & $\mathrm{N}-$ & Coccidia \\
Chloephaga picta & $\mathrm{N}-$ & $\mathrm{N}-$ \\
Aix galericulata & Coccidia & $\mathrm{N}$ - \\
Aix sponsa & Coccidia, Trichuroidea, Ascaridia & Coccidia, Balantidium sp., Trichuroidea, Ascaridia \\
Chenonetta jubata & Coccidia & Coccidia, Trichuroidea \\
Tadorna cana & $\mathrm{N}-$ & Coccidia, Balantidium sp. \\
Tadorna ferruginea & Coccidia & Coccidia, Trichuroidea, Ascaridia \\
Tadorna radjah & Coccidia & Coccidia, Balantidium sp. \\
Tadorna tadorna & Coccidia, Ascaridia & Coccidia, Balantidium sp. \\
Tadorna tadornoides & $\mathrm{N}-$ & Coccidia \\
Tadorna variegata & $\mathrm{N}-$ & Coccidia, Balantidium sp., Ascaridia \\
Lophodytes cucullatus & Trichuroidea & Trichuroidea
\end{tabular}

$\mathrm{N}=$ negative pool

The precise relationship between birds and the cycle of Balantidium sp. has not yet been established in the literature. Thus, the pathogenicity of this parasite in birds remains uncertain, even though it has already been isolated from several species, including passerines, psittacids (Marietto-Gonçalves et al., 2009), pigeons (Borghare et al., 2009) and ostriches (Ponce-Gordo et al., 2011), among others. This is a parasite with zoonotic potential, and birds may serve as a source of infection for humans, especially those who may come into direct contact with birds (Marietto-Gonçalves et al., 2009).

According to Borghare et al. (2009), the presence of cysts of Balantidium sp. in the feces of pigeons reared in Nagpur zoo, in India, was caused by consumption of contaminated water, due to deficient hygiene management. The water provided for the birds used in the present study came from an artesian well, without previous treatment, which makes this a possible source of the parasite.

Another plausible hypothesis for the finding of Balantidium sp. in these anatids is that, according to the owner of the property, some of the birds had been acquired from a pig-rearing establishment. Moreover, the treetops on this property were occupied by large families of howler monkeys; primates and pigs have been noted as the main hosts of this parasite (Gomes, 2009).

Due to the method envolved a qualitative analysis study, it is not possible to classify if one species presented a higher parasitic load than another, however according to the results showed in Table 2, we can conclude that there are positive animals in all species, being Aix galericulata, Aix sponsa, Tadorna cana, Tadorna ferruginea, Tadorna radjah, Tadorna variegate, Lophodytes cucullatus in both collections while Anser Abyssinia, Chloephaga melanoptera, Chloephaga picta, Chenonetta jubata, Tadorna tadornas, Tadorna tadornoides, only in one. Carneiro et al.(2011) also evalueted the presence of parasites in birds using the qualitative percentage existing in the species, although it is noway to evaluete in this present study, if one specie presented a higher infecction than another, because the method was not quantitative.

Coproplus $®$ is a commercial kit that has been on the market for a few years. Its efficacy has been evaluated using human samples (Oliveira, 2019). Its results have shown that the parasites most commonly observed among birds in captivity, using conventional coproparasitological examination methods, are Coccidia, Trichuroidea and Ascaridia), which leads us to trust the sensitivity of this kit. Because of its practicality and cost, comparative tests using conventional analysis methods for gastrointestinal parasites of birds and other animal species would be recommended. 


\section{Conclusions}

There was greatest prevalence of parasites of the order Coccidia (22.22\%), followed by those of the orders Trichuroidea (10.18\%) and Ascaridia (4.63\%). The finding of Balantidium sp., for which uncertainties remain regarding its cycle and relevance in birds, merits further investigation, given that it has zoonotic importance.

\section{References}

Batista AMB, Da Costa Pereira MAV, Vita GF, Barros SCW, Barbosa CG. Diagnóstico coproparasitológico de jacarés (Caiman latirostris DAUDIN, 1802) criados comercialmente no Estado do Rio de Janeiro. Ars Vet 2011; 27(2): 102-110. http://dx.doi. org/10.15361/2175-0106.2011v27n2p102-110.

Borghare AT, Bagde VP, Jaulkar AD, Katre DD, Jumde PD, Maske DK, et al. Incidence of Gastrointestinal parasitism of Captive Wild Pigeons at Nagpur. Vet World 2009; 2(9): 343.

Carneiro MB, Junior AC, Martins IVF. Avaliação coproparasitológica e clínica de aves silvestres e exóticas mantidas em criatórios particulares no município de Alegre - ES. Cienc Anim Bras 2011; 12(3): 525-529. http://dx.doi.org/10.5216/cab.v12i3.6821.

Carvalho EL. Helmintofauna de Cairina moschata doméstica (Anseriforme: Anatidae) na llha de Marajó, Pará. [dissertação]. Belém: Faculdade de Medicina Veterinária da Universidade Federal Rural da Amazônia; 2020.

Corrêa SHR. Estudo epidemiológico de doenças infecciosas em anatídeos da fundação Parque Zoológico de São Paulo. [dissertação]. São Paulo: Faculdade de Medicina Veterinária e Zootecnia da Universidade de São Paulo; 2007.

Figueiredo MAP, Manrique WG, Nogueira RMS. Survey of gastrointestinal parasites of the center for screening of wild animals from São Luís, Maranhão State, Brazil. Ars Vet 2018; 34(2): 60-68. http://dx.doi.org/10.15361/2175-0106.2018v34n2p60-68.

Gomes AIJG. Contribuição para a caracterização do parasitismo gastrointestinal e pulmonar em suínos da raça Alentejana do distrito de Évora. [dissertação]. Lisboa: Faculdade de Medicina Veterinária da Universidade Técnica de Lisboa; 2009.

Gomes FF, Machado HHS, Lemos LS, Almeida LG, Daher RF. Principais parasitos intestinais diagnosticados em galinhas domésticas criadas em regime extensivo na municipalidade de Campos dos Goytacazes, RJ. Cienc Anim Bras 2009; 10(3): 818-822. http:// dx.doi.org/10.5216/cab.v10i3.1095.

Justo FM. Conflito entre anatídeos e produção de arroz: um estudo de caso sobre danos de aves à rizicultura no Cerrado. [dissertação]. Porto Alegre: Faculdade Biociências da Universidade Federal do Rio Grande do Sul; 2019.

Lillehoj HS, Lillehoj EP. Avian coccidiosis. A review of acquired intestinal immunity and vaccination strategies. Avian Dis 2000; 44(2): 408-425. http://dx.doi.org/10.2307/1592556. PMid:10879922.

Lima VFS, Bezerra TL, Andrade AF, Ramos RAN, Faustino MAG, Alves LC, et al. Gastrointestinal parasites of exotic birds living in captivity in the state of Sergipe, Northeastern Brazil. Rev Bras Parasitol Vet 2017; 26(1): 96-99. http://dx.doi.org/10.1590/s198429612016080. PMid:27925071.

López G, Figuerola J, Soriguer R. Time of day, age and feeding habits influence coccidian oocyst shedding in wild passerines. Int J Parasitol 2007; 37(5): 559-564. http://dx.doi.org/10.1016/j.jpara.2006.12.014. PMid:17289051.

Luchese FC, Perin M, Aita RS, Mottin VD, Molento MB, Monteiro SG. Prevalência de espécies de Eimeria em frangos de criação industrial e alternativa. Braz J Vet Res Anim Sci 2007; 44(2): 81-86. http://dx.doi.org/10.11606/issn.1678-4456.bjvras.2007.26645.

Machado GD. Estudo sobre capilariose em psitacídeos e ranfastídeos oriundos da fundação jardim zoológico da cidade do Rio de Janeiro - RIOZOO. [dissertação]. Niterói: Universidade Federal Fluminense; 2014.

Marietto-Gonçalves GA, Martins TF, de Lima ET, Lopes RS, Andreatti Filho RL. Prevalência de endoparasitas em amostras fecais de aves silvestres e exóticas examinadas no Laboratório de Ornitopatologia e no Laboratório de Enfermidades Parasitárias da FMVZ -Unesp/Botucatu-SP. Cienc Anim Bras 2009; 10(1): 349-354. http://dx.doi.org/10.5216/cab.v10i1.1300.

Oliveira CL. Avaliação da sensibilidade dos métodos TF-Test $₫$ e Coproplus $\AA$ no diagnóstico da infecção por Strongyloides stercoralis e outros enteroparasitos em alcoolistas. [dissertação]. Salvador: Universidade Federal da Bahia; 2019.

Pérez CG, Hitos PA, Romero D, Sánchez MM, Pontes A, Osuna A, et al. Intestinal parasitism in the animals of the zoological Garden “Peña Escrita” (Almuñecar, Spain). Vet Parasitol 2008; 156(3-4): 302-309. http://dx.doi.org/10.1016/j.vetpar.2008.05.023. PMid:18639383.

Pérez CG, Hitos PA, Romero D, Sánchez MM, Pontes A, Osuna A, et al. Intestinal and haematic parasitism in the birds of the Almuñecar (Granada, Spain) ornithological garden. Vet Parasitol 2009; 165(3-4): 361-366. http://dx.doi.org/10.1016/j. vetpar.2009.07.027. PMid:19682800.

Ponce-Gordo F, Fonseca-Salamanca F, Martínez-Díaz RA. Genetic Heterogeneity in Internal Transcribed Spacer Genes of Balantidium coli (Litostomatea, Ciliophora). Protist 2011; 162(5): 774-794. http://dx.doi.org/10.1016/j.protis.2011.06.008. PMid:21840258. 
Rennó PP, Queiroz FM, Garcia BP, Prado RNA, Simões MM, Souza JPF, et al. Endoparasitose em aves - revisão de literatura. Rev Cient Elet Med Vet 2008; 6(11): 1-6.

Santana RLS. Epizootiologia de helmintos em patos domésticos provenientes do município de Soure, Ilha de Marajó, Pará. [monografia]. Belém: Faculdade de Medicina Veterinária da Universidade Federal Rural da Amazônia; 2019.

Serrano-Martínez E, Quispe HM, Plascencia PL, Hinostroza ME. Parásitos Zoonóticos en Ranas Destinadas a la Elaboración de Bebidas para el Consumo Humano en Lima, Perú. Rev Investig Vet Peru 2017; 28(3): 642-649. http://dx.doi.org/10.15381/rivep. v28i3.13290.

Sesti L. Biosseguridade na moderna avicultura: Controle integrado de doenças [online]. Campinas: Embrapa; 2005 [cited 2020 Set 18]. Available from: https://www.agencia.cnptia.embrapa.br/Repositorio/biosseguridade_em_avicultura_controle_integrado_ de_doencas_000fyh9f5g002wx5ok0pvo4k3glwvvhl.pdf

Zacarias NVA. Rastreio parasitológico em aves selvagens ingressadas no Centro de Recuperação e Investigação de animais selvagens da Ria Formosa. [dissertação]. Lisboa: Faculdade de Medicina Veterinária da Universidade de Lisboa; 2017. 